\title{
Investigation of Growth, Lipid Productivity, and Fatty Acid Profiles in Marine Bloom-Forming Dinoflagellates as Potential Feedstock for Biodiesel
}

\author{
Steven Jingliang $\mathrm{Xu}^{\dagger}{ }^{\dagger}, \mathrm{Kam}-\mathrm{Chau} \mathrm{Wu}^{\dagger}$, Sophie Cheuk-Yan Chan $₫$, Yiu-Hung Yau, Kin-Ka Chan \\ and Fred Wang-Fat Lee * \\ School of Science and Technology, The Open University of Hong Kong, Hong Kong; sjilxu@ouhk.edu.hk (S.J.X.); \\ kcwuhk2@gmail.com (K.-C.W.); sophieccy905@gmail.com (S.C.-Y.C.); peteryauyh@gmail.com (Y.-H.Y.); \\ chankristof@gmail.com (K.-K.C.) \\ * Correspondence: wflee@ouhk.edu.hk; Tel.:+852-3120-2690 \\ + Authors with equal contributions.
}

Received: 8 April 2020; Accepted: 22 May 2020; Published: 26 May 2020

\begin{abstract}
Microalgae-based biodiesel is increasingly recognized as an alternative to crop-based biodiesel. In this study, 10 local strains of dinoflagellates collected from Hong Kong waters, including a monoculture and field sample of Scrippsiella sp. isolated from an algal bloom, were evaluated against the performance of green alga Tetraselmis suecica. The specific growth rate, biomass production, lipid productivity, and fatty acid profile were investigated. The total lipid content of isolated strains ranged from $16.2 \%$ to $32.2 \%$ of the total dry biomass, whereas palmitic acid (C16:0) and docosahexaenoic acid (DHA, C22:6n3) were dominant in the fatty acid profile. Scrippsiella sp. has a high lipid productivity $(47.3 \mathrm{mg} / \mathrm{L} /$ day) and fatty acid methyl esters (FAME) content (55.2-73 mg/g dry weight (dw)), which were comparable to that in green alga T. suecica. Further, monoculture and field sampled blooming Scrippsiella sp. showed no significant difference in most parameters, suggesting the possibility of harvesting a natural algal bloom population as a mitigation strategy to harmful algal bloom and to use as biodiesel feedstock. Overall, dinoflagellate species showed a slower growth rate $\left(0.04-0.57\right.$ day $\left.^{-1}\right)$ than most compared species $\left(0.07-1.34\right.$ day $\left.^{-1}\right)$, likely due to a large genome size and low chlorophyll to carbon ratio. Notably, most investigated dinoflagellates were not ideal for mass biodiesel production due to the low growth rate and lipid productivity. However, a high level of polyunsaturated fatty acids (PUFA) in dinoflagellates are prospective for further studies in other biotechnological applications. Though effectively harvesting algal blooming biomass can be complex, it can be further explored as a strategy for algal bloom mitigation and potentially creating values at the advantage of natural bloom when applying harvested biomass for biodiesel and bioactive compounds extraction.
\end{abstract}

Keywords: algal biomass; biofuel; biodiesel; dinoflagellates; harmful algal blooms

\section{Introduction}

Biodiesel is alternative to petroleum fuel, which can be derived from crops, such as oilseeds or other materials [1]. Microalgae are unicellular photosynthetic microorganisms living in saline, freshwater, or brackish water environments, converting sunlight, water, and carbon dioxide to algal biomass, which can be further applied for various renewable applications [2-5]. Numerous studies have suggested microalgae as a potentially rich and untapped resource for a wide range of commercial, environmental, pharmaceutical, food, and fuel applications [2,6-9], including the production of microalgae-based biodiesel $[2,10,11]$. Rapid growth and high accumulation of lipids, accounting $20 \%-50 \%$ of dry weight in microalgae biomass have attracted attention as an alternative feedstock 
for biodiesel [12]. Microalgae-based biodiesel is advantageous in effective land utilization, where microalgae can be grown in ponds or bioreactors, yielding higher unit area lipid than biodiesel from terrestrial oilseed crops, such as canola, soybean, and sunflower [2,13]. In addition, crop-based biodiesel is harvested from widely consumed crops, including soybean and palm, which may affect the supply of food or crop-related products, where this issue is negligible in microalgae-based biodiesel. Previous studies have extensively evaluated the potential of various algal species, such as Botryococcus braunii, Cylindrotheca sp., Nannochloropsis sp., Schizochytrium sp., and Neochloris oleoabundans [2,3,13-17], whereas most studies focused on the potential of cyanobacteria, green algae, and diatoms [18], data from marine dinoflagellates for biodiesel production are relatively limited [19].

There is intensive interest in exploring microalgae as alternative feedstock for biodiesel, yet, the commercialization of microalgae-based biodiesel is still hindered by the high cost in operation, mass cultivation, harvesting, and dewatering [20], making it less competitive to petroleum diesel. Varying in scale and location of production, microalgae-based biodiesel from open pond and photo-bioreactors cost US $\$ 0.42-9.11 / \mathrm{L}$ and US $\$ 0.9-22.55 / \mathrm{L}$, respectively [21]; however, it is suggested not to exceed US $\$ 0.526-1.619 / \mathrm{L}$ for microalgae-based biodiesel to be comparable to the price of petroleum diesel [22]. Cost-effective cell harvest may not necessarily indicate a maximized yield. The energy intensive biomass harvesting process made up $20 \%-30 \%$ of the cost [10] and is believed to be a major cause hindering the viability of energy balance in microalgae-based biodiesel. Cell harvest is complicated due to the small size of microalgae, diluted suspension of cells, similar density of algal cells with growth medium, and the frequent harvest due to rapid growth [23]. Sedimentation, centrifugation, filtration, flocculation, and flotation can be adopted individually or in combination for cell harvest and dewatering depending on properties of microalgal species, such as its density, shape, size, and the presence of a cell wall [24]. Non-toxic interventions and a recovering culture medium in cell harvest can further save costs by recycling the medium in cultivation [25].

Dinoflagellates are one of the harmful algal blooming (HABs) causative agents in the world. They are widely distributed along the coast of China, which can be found in Dapeng Bay, Daya Bay, Pearl River Estuary, and Tolo Habour in Hong Kong. In algal blooming events, these massive naturally occurring microalgal biomass can reach millions of cells per liter, discoloring surface water into red or brown that gives rise to the term red tide. There are around 330 aquatic species known to cause red tide globally and 70 of them, mainly harmless strains, constantly cause HABs in Hong Kong waters each year [26]. Under climate change and anthropogenic drivers, an expanded range and an increased frequency of HAB have been observed [27] and are expected to deteriorate in the future. Despite the fast growing advancement in microalgal-related biotechnology, dinoflagellates, and particularly HAB species have received less attention, where their potential biotechnological applications are still largely unexplored. Recently, studies showed potential pharmaceutical uses of biotoxin and bioactive molecules from dinoflagellates, such as for anti-cancer and anti-inflammation $[8,28,29]$. High value metabolites allow economic utilization of algal biomass [30], which makes dinoflagellate attractive for further investigation in their biotechnological potentials. For biodiesel extraction, few dinoflagellate species have been discussed, which include Karlodinium veneficum, Alexandrium andersoni, Amphidinium carterae, and Alexandrium minutum [19,30,31].

To screen locally isolated algal bloom causative dinoflagellate strains for further evaluation as potential biodiesel feedstock, strain-specific growth rates, biomass productivity, lipid productivity, fatty acid methyl esters (FAME) content, and fatty acid profile of ten dinoflagellate strains were analyzed in this study. Moreover, the potential use of natural HAB biomass for biodiesel were discussed by comparing the performance of the dinoflagellate monoculture grown in the laboratory and a field sample of blooming population both collected in the same algal bloom event. As extensive water requirement is one of the constraints in sustainably harvesting biodiesel from microalgae [25], the use of an indigenous marine bloom-forming dinoflagellate population may salvage from unfavorable yet natural red tide events. 


\section{Materials and Methods}

\subsection{Algal Sampling and Cultivation Conditions}

Algal samples were collected from Hong Kong coastal waters (Figure 1) using a $10 \mu \mathrm{m}$ mesh plankton net and transferred to the laboratory. Algal strains were isolated in samples since 1997 (Table 1). After the isolation of a single algal cell for monoculture, isolates were placed in a growth chamber (Conviron) set at $24 \pm 1{ }^{\circ} \mathrm{C}$, ambient $\mathrm{CO}_{2}$ level (0.03\%), 12:12 h of light:dark cycle, and with a light intensity of $120 \mu \mathrm{E} \mathrm{m}^{-1} \mathrm{~s}^{-1}$ supplied by cool white fluorescent tubes. Ten monocultures of dinoflagellate strains were used in the present study. To evaluate the fatty acid profile of the natural algal blooming population as potential biodiesel feedstock, a field sample of Scrippsiella sp. biomass was analyzed directly after collection and compared to the monoculture strain isolated from the same unialgal bloom. Green alga Tetraselmis suecica (CCMP904, obtained from National Center for Marine Algae and Microbiota), one of the marine microalgae readily studied for oil production [32-34], was analyzed in parallel with the isolated dinoflagellate strains on growth and lipid productivity. All cultures were maintained in a natural seawater-based L1 medium (30 psu, pH 8.0) [35]. Seawater was collected from Tolo Harbour and filtered with a $0.45 \mu \mathrm{m}$ nylon membrane (Millipore, Billerica, MA, USA) prior to autoclave. Cultures were kept at an exponential growth phase by transferring to a new medium every week in 1:10 $v / v$, with regular monitoring under the microscope for possible contamination.

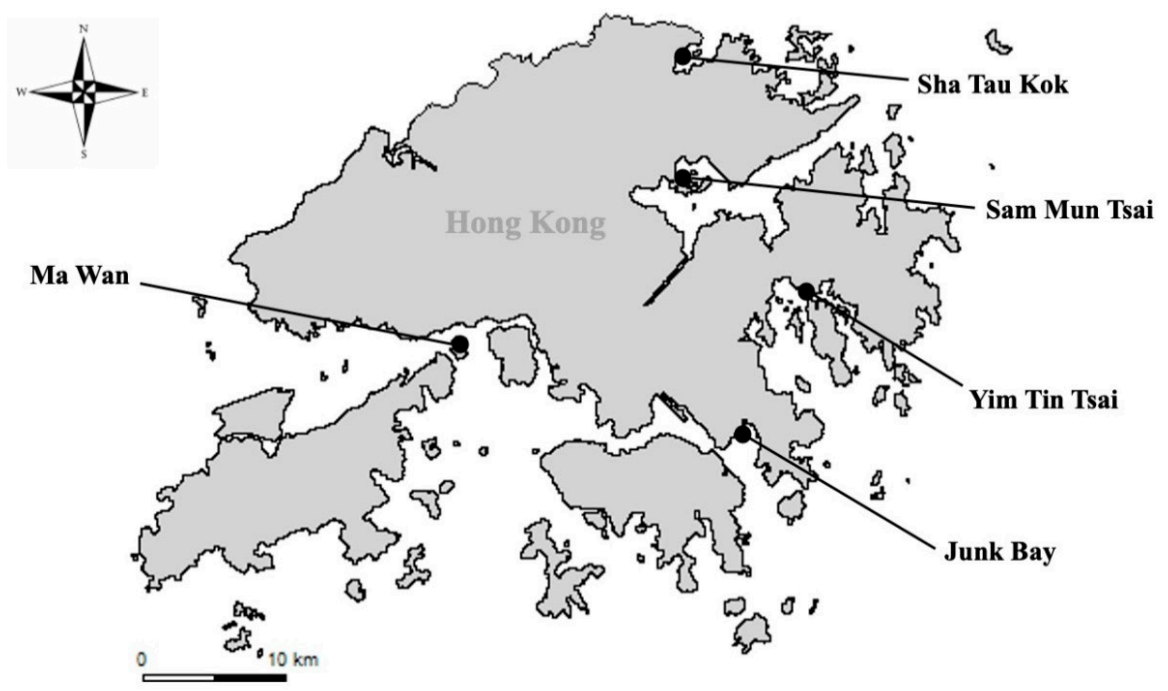

Figure 1. Isolation sites of various dinoflagellate strains used in this study.

Table 1. The dinoflagellate strains used in this study.

\begin{tabular}{cccc}
\hline Species & Strain & Isolation Site & Date of Isolation \\
\hline \multirow{2}{*}{ Prorocentrium minimum } & $\mathrm{a}$ & Yim Tin Tsai & 2005 \\
& $\mathrm{~b}$ & Junk Bay & 1998 \\
\hline Scrippsiella sp. & $\mathrm{a}$ & Ma Wan & 2011 \\
\hline \multirow{2}{*}{ Prorocentrium triestinum } & $\mathrm{b}^{\wedge}$ & Sam Mun Tsai & 2012 \\
\hline Scrippsiella rotunda & $\mathrm{a}$ & Junk Bay & 1997 \\
\hline Alexandrium affine & $\mathrm{b}$ & Sha Tau Kok & 2011 \\
\hline Polykrikos geminatum & - & Junk Bay & 1997 \\
\hline Akashiwo sanguinea & - & Junk Bay & 1998 \\
\hline
\end{tabular}

^Field sample of blooming population Scrippsiella sp. was also collected. 


\subsection{Algal Species Identification}

The isolated algal cultures were identified by morphological examination under a microscope (1000×, Leica DM500, Leica Microsystems, Heerbrugg, Switzerland) or by DNA sequencing. Procedures for DNA purification, amplification, and sequencing were followed as described in [36], purified genomic DNA was extracted by a DNA extraction kit (Roche, Switzerland). The internal transcribed spacer (ITS) regions were amplified from the purified genomic DNA using ITS 1 (5'TCCGTAGGTGAACCTGCG 3') and ITS4 (5' TCCTCCGCTTATTGATATGC 3') primers [37,38]. These primers amplify ITS regions that contain 5.8S rDNA. PCR amplification was performed with C1000 Touch Thermal Cycler (Bio-Rad Laboratories, Hercules, CA, USA) at $95^{\circ} \mathrm{C}$ for $5 \mathrm{~min}$, followed by 35 cycles of $45 \mathrm{~s}$ at $94{ }^{\circ} \mathrm{C}, 45 \mathrm{~s}$ at $55{ }^{\circ} \mathrm{C}$, and $2 \mathrm{~min}$ at $72{ }^{\circ} \mathrm{C}$, and final extension at $72{ }^{\circ} \mathrm{C}$ for $10 \mathrm{~min}$. Amplicons were cloned into pGEM-T easy vectors (Promega, Madison, WI, USA) followed by DNA sequencing using the traditional dideoxy method performed by commercial facilities (1st BASE Ltd., Singapore).

Sequencing data were determined by the BLAST program and compared with published complete sequences in GenBank. Sequences were aligned by the Clustal X program [39], and the nucleotides difference was compared with the GeneDoc program [40]. The percentage of nucleotide similarity was calculated as $\mathrm{P}=(\mathrm{N}-\mathrm{Nd}) / \mathrm{N} \times 100 \%$, where $\mathrm{N}$ and $\mathrm{Nd}$ are the total number of the nucleotide position compared and the total number of nucleotides differ between the sequences, respectively.

\subsection{Determination of Growth Rate in Algal Strains}

To unravel specific growth rates at an exponential growth phase and the maximum cell abundance, growth curves (Supplementary Figure S1) were established for each algal strain in the L1-medium. Cells were fixed with Lugol's solution and counted under a light microscope using a Sedgwick-Rafter cell counter.

The specific growth rate $(\mu)$ for the exponential growth phase was calculated using the following equation:

$$
\mu=\left(\operatorname{In} N_{1}-\operatorname{In} N_{0}\right) / t_{1}-t_{0}
$$

where $N_{0}$ and $N_{1}$ are the cell density reading at time $t_{0}$ and $t_{1}$.

\subsection{Determination of Algal Biomass and Total Lipid Content}

Ten milliliters of culture suspension was filtered through pre-weighed GF/C glass fiber filters (Whatman GF/F, $47 \mathrm{~mm}$, nominal pore size $0.7 \mathrm{um}$ ). During the filtration, the vacuum pressure differentials were maintained between 35 and $55 \mathrm{~mm} \mathrm{Hg}$ [41]. After filtration, the filter setup was rinsed with $0.45 \mu \mathrm{m}$ filtered natural seawater, and the filters were dried at $75^{\circ} \mathrm{C}$ for $24 \mathrm{~h}$ until a consistent weight was attained. The weight difference of the filter before and after filtration was determined as the algal biomass in dry weight $(\mathrm{dw})$.

Total lipids were extracted from freeze-dried microalgal biomass using a modified method from Bligh and Dyer [42]. The lipids were extracted with chloroform-methanol (1:1 v/v), and then separated into chloroform and aqueous methanol layers by the addition of $5 \% \mathrm{NaCl}$ solution to a final solvent ratio of chloroform:methanol:5\% $\mathrm{NaCl}$ solution of 2:2:1. The chloroform layer was collected and evaporated to dryness by a nitrogen flow. The total lipids were measured gravimetrically.

\subsection{Determination of Fatty Acid Profile in Algal Strains}

Fatty acids in microalgae underwent modified direct transesterification described by [43] to establish a fatty acid methyl esters (FAMEs) profile. Triplicates of $50 \mathrm{mg}$ of samples were mixed with the transesterification reagent (i.e., $100.0 \mathrm{~mL}$ methanol containing $2.2 \mathrm{~mL}$ of sulphuric acid, $98 \%$ purity) and stirred for $2 \mathrm{~h}$ at $90{ }^{\circ} \mathrm{C}$ under reflux. The reaction product was then extracted with a hexane:water mixture $(1: 1 v / v)$. The FAME profile was determined by the capillary column gas chromatographic method. The FAME separation was performed on a gas chromatograph (Perkin Elmer 
GC 600) equipped with a flame ionization detector and a fused silica capillary column Omegawax ${ }^{\mathrm{TM}}$ $250\left(30 \mathrm{~m} \times 0.25 \mathrm{~mm} \times 0.25 \mu \mathrm{m}\right.$ film thickness). The injector temperature was $250{ }^{\circ} \mathrm{C}$, the detector temperature was $260^{\circ} \mathrm{C}$, and the injection was split at a 50:1 ratio. The thermal program was initially held at $150{ }^{\circ} \mathrm{C}$ for $16 \mathrm{~min}$, then ramped at $2{ }^{\circ} \mathrm{C} / \mathrm{min}$ to $180^{\circ} \mathrm{C}$ and held for $25 \mathrm{~min}$, and finally ramped at $5^{\circ} \mathrm{C} / \mathrm{min}$ to $210^{\circ} \mathrm{C}$ and held for $25 \mathrm{~min}$. Helium was used as carrier gas at $1.3 \mathrm{~mL} / \mathrm{min}$. Nitrogen gas was used as makeup gas $(30 \mathrm{~mL} / \mathrm{min})$; the flow of hydrogen gas and synthetic air were provided at 30 and at $300 \mathrm{~mL} / \mathrm{min}$, respectively. The injections were performed with $1 \mu \mathrm{L}$ in duplicate. FAMEs were identified by comparing the retention time with those in FAME mixed standard (18919-1AMP, Supelco) and heptadecanoic acid. Furthermore, C17:0 (Sigma-Aldrich R, St. Louis, MO, USA) was used as the internal standard. Fatty acids were expressed in $\%$ of total FAME, and the FAME yield was expressed in $\mathrm{mg} / \mathrm{g} \mathrm{dw}$.

\section{Results and Discussion}

\subsection{Identification of Isolated Algal Species}

In this study, the potential as biodiesel feedstock in terms of growth, lipid productivity, FAME content, and fatty acid profile were investigated in 11 strains of microalgal cultures, including 10 strains of HAB-causing dinoflagellates and the green alga T. suecica. Microscopic observation of the cultures revealed its colonial existence and purity (Figure 2). By morphological examination and DNA sequencing, seven algal species were documented in the 10 isolated dinoflagellate strains: Prorocentrum minimum (strain a, b), Prorocentrum triestinum (strain a, b), Scrippsiella sp. (strain a, b), Scrippsiella rotunda, Alexandrium affine, Polykrikos geminatum, and Akashiwo sanguinea. In pairs of species in which two isolates were identified: P. minimum, P. triestinum, and Scrippsiella sp., they shared $92 \%-100 \%$ of similarity on the ITS sequence analysis (Table 2 ).

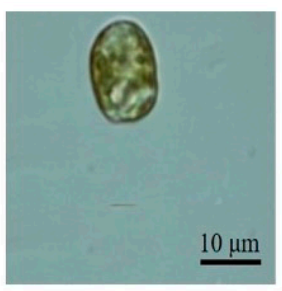

Prorocentrium minimum

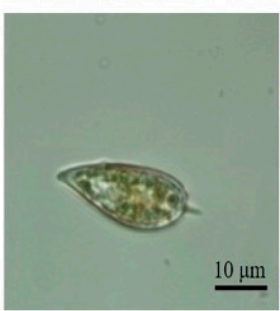

Prorocentrium triestinum

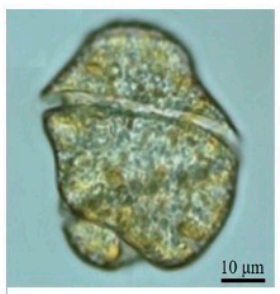

Polykrikos geminatum

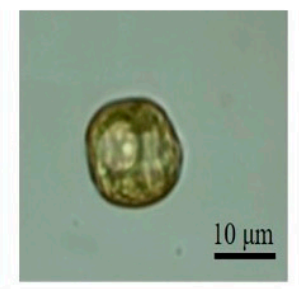

Prorocentrium minimum

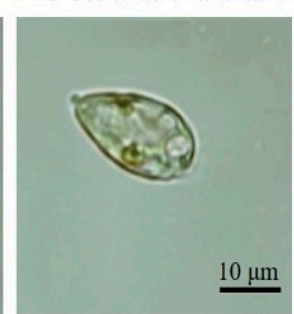

Prorocentrium triestinum

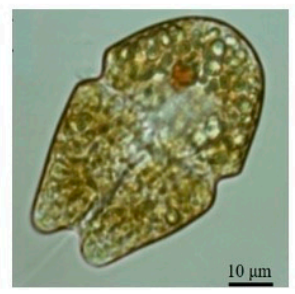

Akashiwo sanguinea

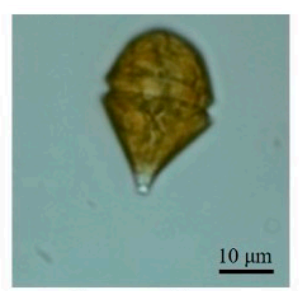

Scrippsiella $s p$.

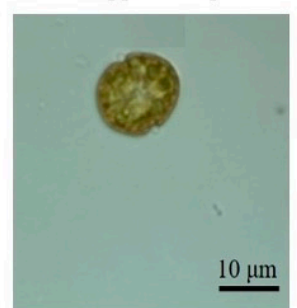

Scrippsiella rotunda

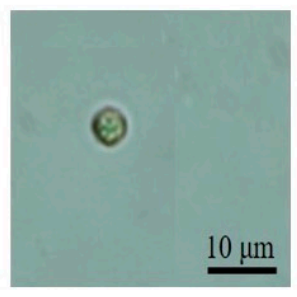

Tetraselmis suecica

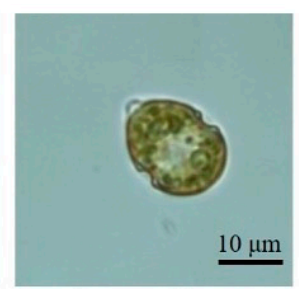

Scrippsiella sp.

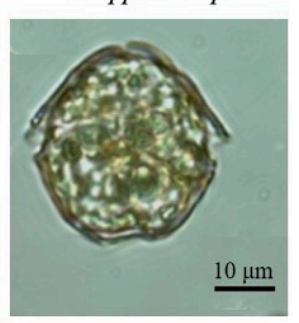

Alexandrium affine

Figure 2. Morphology of algal strains used in this study under a light microscope $(1000 \times)$. 
Table 2. Sequence analysis of dinoflagellate strains of the same species.

\begin{tabular}{|c|c|c|c|}
\hline Species & Strain & Location of Isolation & Sequence Similarity (\%)^ \\
\hline Prorocentrum minimum & a & Yim Tin Tsai & \multirow{2}{*}{99} \\
\hline Prorocentrum minimum & $\mathrm{b}$ & Junk Bay & \\
\hline Scrippsiella sp. & a & Ma Wan & \multirow[b]{2}{*}{92} \\
\hline Scrippsiella sp. & $\mathrm{b}$ & Sam Mun Tsai & \\
\hline Prorocentrum triestinum & a & Junk Bay & \multirow{2}{*}{100} \\
\hline Prorocentrum triestinum & $\mathrm{b}$ & Sha Tau Kok & \\
\hline
\end{tabular}

^Internal transcribed spacer (ITS) regions (ITS1-5.8s-ITS2) were amplified and compared.

\subsection{Growth Rate and Biomass of Selected Algal Strains}

Growth rate has been one of the most studied parameters in screening microalgae for a large-scale cultivation in biofuel production [44]. An initial screening indicated that some strains were promising biodiesel feedstock with a high growth rate and biomass production. The net growth rates were diverse among the examined species (Table 3). Among all strains, T. suecica had the highest growth rate at 0.72 day $^{-1}$ (one division every 1.38 days) during the exponential phase of growth and reached the maximum cell abundance of $1.3 \times 10^{6} \mathrm{cell} / \mathrm{mL}$ at day 10 . Among the isolated dinoflagellate strains, there was high variability in growth rates, ranging between 0.04 and 0.57 day $^{-1}$. Notable differences were found between isolates of P. triestinum $\left(0.05\right.$ day $^{-1}$ and 0.57 day $\left.^{-1}\right)$ and Scrippsiella sp. $\left(0.19\right.$ day $^{-1}$ and 0.28 day $\left.^{-1}\right)$. However, there was no significant difference between strains of P. minimum ( 0.38 day $^{-1}$ and 0.39 day $^{-1}$ ). A strain-specific growth rate and diverse responses to stressors and environmental changes in microalgae have been documented, possibly attributed by intraspecific genetic diversity accounting strain variability within algal population [45-47]. Metabolic variation may also partly account for the differential responses as they were collected at different times and locations of different environmental conditions. In the present study, Scrippsiella sp. (strain a) was collected in the transitional water zone in Hong Kong while Scrippsiella sp. (strain b) was collected in the eastern water zone during an algal bloom. They may belong to different genotypes where metabolic activities and responses are likely to be different.

In view of maximum cell density, the green alga T. suecica achieved high cell abundance in a relatively shorter growth period $\left(1.3 \times 10^{6} \mathrm{cell} / \mathrm{mL}\right.$ in 10 days), and in general two-fold higher in maximum cell number than the examined dinoflagellate strains. For Scrippsiella sp. (strain b) and P. minimum (strain a), maximum cell abundance between 10 and 14 days at $1.7 \times 10^{4}$ and $2.8 \times 10^{5}$ cell $/ \mathrm{mL}$, respectively, was reached. For other dinoflagellate strains, maximum abundance at $5.7 \times 10^{3}$ to $3.8 \times 10^{5}$ cell $/ \mathrm{mL}$ was reached at $16-24$ days. The highest cell abundance in dinoflagellate isolates was P. triestinum (strain b) with $3.8 \times 10^{5} \mathrm{cell} / \mathrm{mL}$ (at day 18), whereas $A$. sanguinea had the lowest cell number at $5.7 \times 10^{3} \mathrm{cell} / \mathrm{mL}$ (at day 16). Biomass is related to bio-volume and abundance in which T. suecica showed the highest cell abundance and also corresponded to the highest biomass concentration $(1.82 \mathrm{~g} / \mathrm{L})$ among all tested strains. For the selected dinoflagellate strains, the biomass concentration harvested in the stationary phase varied between 1.05 and $1.48 \mathrm{~g} / \mathrm{L}$ (Table 3), with over $1.3 \mathrm{~g} / \mathrm{L}$ biomass in P. minimum (strain a), Scrippsiella sp. (strain b), and the field sample Scrippsiella sp. As all monocultural strains were grown at the same laboratory condition, it may not be the optimum for all the analyzed strains, and performance in growth and biomass production may vary if other growth conditions were adopted.

For initial strain screening, rapid growth and high biomass concentration are two desirable characteristics for biodiesel production. Seemingly, the green alga T. suecica was a more prospective candidate and its remarkable performance was aligned to what has been reported in the literatures [2-5]. Among the dinoflagellates, P. minimum (strain a), Scrippsiella sp. (strain b), and the field sample Scrippsiella sp. were also relatively favorable to be further evaluated for biodiesel application. Algal growth is directly affected by the availability of nutrients, light, the stability of $\mathrm{pH}$, temperature, and 
the density of initial inoculum [44]. Refining the culture conditions may alter the growth for a more efficient production of microalgae-based biodiesel. Though a lower growth rate and/or small cell size contribute to lower biomass productivity, it may not necessarily imply a low lipid content [48], the consideration on a total lipid and fatty acid profile in different algal strains was also very important.

Table 3. Growth rate, biomass, lipid content, and lipid productivity of the selected algal strains in the present study compared to reported values of freshwater and marine species. Data expressed as mean $\pm S D(n=3)$ for the present study; mean values were adopted from literatures.

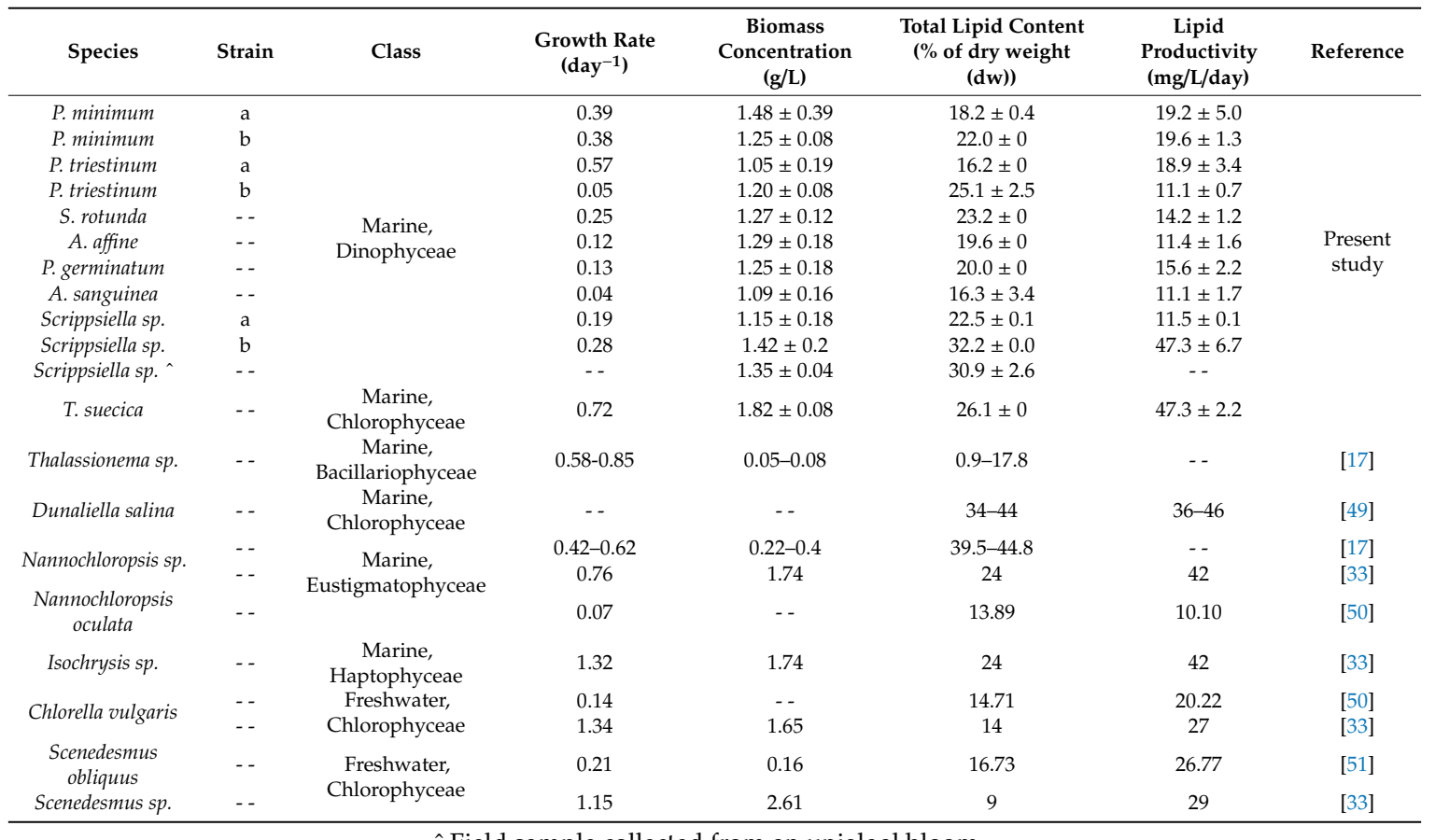

^Field sample collected from an unialgal bloom.

\subsection{Lipid Content and Productivity of Selected Algal Strains}

The total lipid content is one of the key criteria for screening algal strain containing a high intracellular lipid content for biodiesel feedstock production [44]. The total lipid content and lipid productivity of algal strains are listed in Table 3. Overall, the locally isolated dinoflagellate strains accumulated lipid at $16.2 \%-32.2 \% \mathrm{dw}$, and approximately half of the isolated marine dinoflagellate strains contained over $20 \%$ of total lipid as biomass. The values were comparable to those reported in Bacillariophyceae, Chlorophyceae, and Cyanophyceae, ranging from $5 \%$ to $57 \%, 1.9 \%$ to $62 \%$, and $4 \%$ to $11 \% \mathrm{dw}$ of lipids, respectively [52]. The total lipid content of P. triestinum (strain b), T. suecica, Scrippsiella sp. (strain b), and the field sample Scrippsiella sp. exceeded $25 \%$ of $\mathrm{dw}$, whereas S. rotunda, P. minimum (strain b), Scrippsiella sp. (strain a), and P. germinatum had a total lipid content of over $20 \%$ of $\mathrm{dw}$. The highest lipid content was noted in Scrippsiella sp. (strain b, 32.2\% of dw) which is a pure monoalgal culture isolated from algal bloom. It should be noticed that the lipid content of the Scrippsiella sp. field sample was not significantly different $(p>0.05$, data not shown) from the laboratory cultured Scrippsiella sp. Slight strain differences in the total lipid content were found in between strains of P. minimum $(18.2 \%-22 \% \mathrm{dw})$ and P. triestinum $(16.2 \%-25.1 \% \mathrm{dw})$. Moreover, there was a notable difference of approximately $10 \% \mathrm{dw}$ of lipid between Scrippsiella sp. isolated from the blooming population (strain $\mathrm{b}$ and field sample) and non-blooming population (strain a).

Accounting with growth rates and biomass production, the lipid productivity of isolated dinoflagellate strains were between 11.1 and $47.3 \mathrm{mg} \mathrm{L}^{-1} \mathrm{day}^{-1}$. All dinoflagellate strains have lipid productivity below $20 \mathrm{mg} / \mathrm{L} /$ day, except Scrippsiella $s p$. (strain b). Owing to a relatively high lipid 
content $(32.2 \% \mathrm{dw})$ and short period to reach maximum cell capacity, Scrippsiella sp. (strain b) has comparable lipid productivity as the green alga T. suecica (both at $47.3 \mathrm{mg} \mathrm{L}^{-1} \mathrm{day}^{-1}$ ).

\subsection{Comparison of Growth and Lipid Productivity with Other Freshwater and Marine Species}

Growth rate, biomass concentration, lipid content, and lipid productivity of dinoflagellate strains in the present study were compared to reported values of several commonly assessed algal species for biodiesel feedstock, including marine species Thalassionema sp., D. salina, Nannochloropsis sp., and Isochrysis sp., as well as freshwater species C. vulgaris and Scenedesmus sp. (Table 3). Overall, dinoflagellate species showed a slower growth rate $\left(0.04-0.57\right.$ day $\left.^{-1}\right)$ than most compared species $\left(0.07-1.34\right.$ day $\left.^{-1}\right)$, likely due to the large genome size and low chlorophyll to carbon ratio [53]. Reported biomass values showed great variation where total lipid content in dinoflagellates were comparable to other species, generally below $30 \%$ of $\mathrm{dw}$, except for selected Scrippsiella sp. $(30.9 \%-32.2 \%)$ in the present study and previously reported in D. salina $(34 \%-44 \%)$ and selected Nannochloropsis sp. $(39.5 \%-44.8 \%)$. For lipid productivity, most dinoflagellate species have low lipid productivity, below $20 \mathrm{mg} / \mathrm{L} /$ day, whereas most other reported species ranged at $20 \%-46 \% \mathrm{mg}$ lipid/L/day. Only Scrippsiella sp. (strain b, $47.3 \mathrm{mg} / \mathrm{L} /$ day) was comparable to reported values in marine species D. salina, Nannochloropsis sp., and Isochrysis sp. (36-46 mg/L/day). Slow growth in dinoflagellates was a major factor leading to much lower lipid productivity than other algal classes, which suggests that dinoflagellates were in general not prospective for mass cultivation for harvesting lipids, or careful selection for fast-growing strains is required.

\subsection{Fatty Acid Composition of Selected Algal Strains}

The cetane number $(\mathrm{CN})$, combustion heat, cold filter plugging point (CFPP), oxidative stability, kinematic viscosity, lubricity, and fatty acid profile are some properties to determine the performance of fuel as desirable biodiesel [54]. Twelve fatty acids were differentiated from the algal strain extracts (Table 4), where palmitic acid (C16:0) and docosahexaenoic acid (DHA, C22:6n3) were present in all analyzed dinoflagellate strains, ranging between $10.4 \%$ and $25.2 \%$ and $47.5 \%$ and $84 \%$ of FAME, respectively. Palmitic acid was also the dominant fatty acid in T. suecica where DHA was not present. In general, algal extracts were common in C16:0, $\alpha$-linolenic acid (C18:3n3), erucic acid (C22:1n9), and docosahexaenoic acid (DHA, C22:6n3). If present, their percentages in FAME were $3.6 \%-23.5 \%$ for $\mathrm{C} 18: 3 \mathrm{n} 3$, and $3.2 \%-55.2 \%$ for $\mathrm{C} 22: 1 \mathrm{n} 9$. The lipid profile in algal extracts was slightly different from that of vegetable oil-based biodiesel, which were common in C16:0, stearic acid (C18:0), oleic acid (C18:1), linoleic acid (C18:2), and linolenic acid (C18:3) [1,2,55].

Ignition quality can be estimated by the cetane number; higher ignition quality correlates to a higher cetane number, longer chain length, and lower unsaturation [56], i.e., a cetane number of 85.9 for saturated ester (C16:0) and 22.7 for polyunsaturated ester (C18:3n3) [1,57]. C16:0 was commonly present in algal strains for combustion as biodiesel, which was of higher proportion of FAME in T. suecica ( $25.2 \%)$, P. triestinum (strain b, 18.6\%), and P. minimum (strain b, 17.8\%). Oxidative stability and low temperature properties have been suggested as common technical difficulties faced by biodiesel [1]. In terms of oxidative stability, polyunsaturated fatty acids (PUFA) such as linoleic (C18:2) and linolenic (C18:3) acids are more susceptible to oxidation, creating biodiesel instability issues. The linolenic acid methyl ester content is also specified not to exceed 12\% in The Biodiesel Fuel Testing Europe (EN-14214) [58], suggesting FAME from P. triestinum (strain b), P. minimum (strain a and b), Scrippsiella sp. (strain a), and S. rotunda, with $15.4 \%-23.5 \%$ of linolenic acid content were not suitable for use as biodiesel. For low temperature applications, increasing unsaturation such as enriching with oleic acid (C18:1n9) or palmitoleic acid (C16:1n7) could lower the melting point and cold-filtering plugging point that improve the performance at a low temperature $[1,55]$. 
Table 4. Fatty acid composition ( $\%$ of total fatty acid methyl esters (FAME)) in selected algal strains. Data expressed as mean \pm SD $(n=3)$.

\begin{tabular}{|c|c|c|c|c|c|c|c|c|c|c|c|c|}
\hline \multirow{2}{*}{$\begin{array}{l}\text { Species } \\
\text { Strain }\end{array}$} & \multicolumn{2}{|c|}{ P. minimum } & \multicolumn{2}{|c|}{ P. triestinum } & \multicolumn{3}{|c|}{ Scrippsiella sp. } & \multirow{2}{*}{$\begin{array}{c}\text { A. sanguinea } \\
-\end{array}$} & \multirow{2}{*}{$\begin{array}{c}\text { P. germinatum } \\
-\end{array}$} & \multirow{2}{*}{$\begin{array}{c}\text { A. affine } \\
-\end{array}$} & \multirow{2}{*}{$\frac{\text { S. rotunda }}{-}$} & \multirow{2}{*}{$\begin{array}{c}\text { T. suecica } \\
-\end{array}$} \\
\hline & $\mathrm{a}$ & $\mathrm{b}$ & $\mathrm{a}$ & $\mathrm{b}$ & $\mathrm{a}$ & $\mathrm{b}^{*}$ & Field sample^ & & & & & \\
\hline Myristic acid (C14:0) & $2.7 \pm 0.8$ & N.D. & N.D. & $2.1 \pm 0.2$ & N.D. & $2.7 \pm 0.4$ & $3.6 \pm 0.0$ & $2.2 \pm 0.8$ & $3.8 \pm 1.4$ & N.D. & $1.3 \pm 0.2$ & $6.2 \pm 0$ \\
\hline Pentadecanoic acid (C15:0) & N.D. & N.D. & N.D. & N.D. & N.D. & N.D. & N.D. & N.D. & N.D. & N.D. & N.D. & N.D. \\
\hline Palmitic acid (C16:0) & $10.4 \pm 0.8$ & $17.8 \pm 2.9$ & $11.3 \pm 0$ & $18.6 \pm 3.6$ & $11.4 \pm 0.4$ & $17.1 \pm 0.0$ & $11.1 \pm 0.3$ & $15.5 \pm 1.4$ & $15.2 \pm 0.5$ & $16.8 \pm 0.2$ & $13.5 \pm 0.9$ & $25.2 \pm 1.4$ \\
\hline Palmitoleic acid (C16:1n7) & N.D. & N.D. & N.D. & $3.5 \pm 0.7$ & N.D. & N.D. & N.D. & N.D. & N.D. & N.D. & N.D. & $15.9 \pm 0$ \\
\hline cis-10-Heptadecenoic Acid (C17:1) & N.D. & N.D. & N.D. & N.D. & $1.4 \pm 0.4$ & N.D. & N.D. & N.D. & N.D. & N.D. & N.D. & $5.1 \pm 0$ \\
\hline Stearic acid (C18:0) & N.D. & N.D. & N.D. & $1.8 \pm 2.5$ & $1.7 \pm 0.8$ & $2.1 \pm 0.1$ & $1.4 \pm 0.1$ & $3.1 \pm 1.4$ & $3.0 \pm 0.5$ & N.D. & $1.73 \pm 0.2$ & $7.5 \pm 0$ \\
\hline Oleic acid (C18:1n9) & N.D. & N.D. & N.D. & N.D. & N.D. & $2.2 \pm 0.1$ & $1.4 \pm 0.1$ & $4.5 \pm 3.2$ & $3.3 \pm 0.2$ & N.D. & N.D. & $13.6 \pm 0$ \\
\hline Linoleic acid (C18:2n6) & N.D. & N.D. & N.D. & N.D. & N.D. & $1.2 \pm 0.3$ & $0.2 \pm 0.3$ & N.D. & N.D. & N.D. & N.D. & $11.8 \pm 1.1$ \\
\hline$\gamma$-Linolenic acid (C18:3n6) & N.D. & N.D. & N.D. & N.D. & N.D. & $9.9 \pm 0.4$ & $4.0 \pm 0.6$ & N.D. & N.D. & N.D. & N.D. & $8.5 \pm 0$ \\
\hline$\alpha$-Linolenic acid (C18:3n3) & $19.3 \pm 4.5$ & $15.4 \pm 1.5$ & $3.6 \pm 0.2$ & $23.5 \pm 1.6$ & $18.8 \pm 4.7$ & N.D. & N.D. & N.D. & $5.1 \pm 1.7$ & $6.4 \pm 0.2$ & $18.3 \pm 0.8$ & $3.8 \pm 1.3$ \\
\hline cis-11-Eicosapentaenoic Acid (C20:1) & $3.7 \pm 0.1$ & $2.6 \pm 0.1$ & $1.2 \pm 0.0$ & $3.4 \pm 0.1$ & $4.2 \pm 0.8$ & $4.6 \pm 0.0$ & $16.0 \pm 0.0$ & N.D. & N.D. & $4.8 \pm 0.8$ & $3.48 \pm 0.3$ & N.D. \\
\hline Arachidonic acid (C20:4n6)(AA) & N.D. & N.D. & N.D. & N.D. & N.D. & N.D. & N.D. & N.D. & N.D. & N.D. & N.D. & N.D. \\
\hline $\begin{array}{l}\text { cis-5,8,11,14,17-Eicosapentaenoic } \\
\text { acid (C20:5n3)(EPA) }\end{array}$ & N.D. & N.D. & N.D. & N.D. & N.D. & N.D. & N.D. & N.D. & N.D. & N.D. & N.D. & N.D. \\
\hline Behenic acid (C22:0) & N.D. & N.D. & N.D. & N.D. & N.D. & N.D. & N.D. & N.D. & N.D. & N.D. & N.D. & N.D. \\
\hline Erucic acid (C22:1n9) & $7.2 \pm 2.2$ & N.D. & N.D. & N.D. & N.D. & $3.2 \pm 0.2$ & $9.5 \pm 1.8$ & $16.8 \pm 2.3$ & $17.0 \pm 6.7$ & $16.4 \pm 0.1$ & N.D. & N.D. \\
\hline $\begin{array}{l}\text { Docosahexaenoic acid } \\
\text { (C22:6n3)(DHA) }\end{array}$ & $56.6 \pm 8.4$ & $64.2 \pm 1.4$ & $84 \pm 8.0$ & $47.5 \pm 4$ & $60.5 \pm 4.5$ & $57.1 \pm 0.4$ & $52.7 \pm 2.9$ & $57.9 \pm 7.5$ & $52.4 \pm 6.6$ & $55.6 \pm 1.0$ & $61.7 \pm 1.4$ & N.D. \\
\hline Lignoceric acid (C24:0) & N.D. & N.D. & N.D. & N.D. & N.D. & N.D. & N.D. & N.D. & N.D. & N.D. & N.D. & N.D. \\
\hline
\end{tabular}

* Monoculture of Scrippsiella $s p$. in laboratory isolated from an unialgal bloom; ${ }^{\wedge}$ field-sampled Scrippsiella $s p$. from an unialgal bloom analyzed directly after collection. N.D.: concentration not detectable. 
FAME derived from algal extracts ranging from 21.8 to $73 \mathrm{mg} / \mathrm{g} d \mathrm{w}$ (Table 5). Field sample Scrippsiella sp. showed the highest FAME content $(73 \mathrm{mg} / \mathrm{g} \mathrm{dw})$, followed by cultured Scrippsiella sp. (strain b) and T. suecica, having over $50 \mathrm{mg} / \mathrm{g} \mathrm{dw}$, and P. triestinum (strain b), S. rotunda, and Scrippsiella sp. (strain a) had over $30 \mathrm{mg} / \mathrm{g} \mathrm{dw}$. The identified fatty acids were categorized and showed great species variation in saturated fatty acids (SFA, $11.3 \%-44.9 \%$ of FAME), monounsaturated fatty acids (MUFA, $2.3 \%-55.2 \%$ of FAME), and PUFA (1.3\%-87.5\% of FAME). The isolated dinoflagellate strains accumulated mostly PUFA ( $58 \%-87.5 \%$ of FAME), especially DHA ( $47.5 \%-84 \%$ of FAME). To improve the quality of lipid in microalgae for biodiesel, reducing the nutrient supply (e.g., nitrogen depletion) and refining cultivation conditions may influence the unsaturated fatty acid profile for a better performance as biodiesel [15].

A high proportion of SFA and a low proportion of PUFA are considered optimal for biodiesel $[1,59,60]$, with MUFA components that may increase oxidative stability for prolonged storage and the use in cold regions [1]. Aligned with the above selection criteria, green alga T. suecica showed the most potential in biodiesel application with a high FAME content, as well as a relatively high proportion of SFA and MUFA (over 30\% of FAME). Both field and cultured Scrippsiella sp. also had high FAME yield with a considerable proportion of SFA $(16.1 \%-22.8 \%)$ and MUFA $(9.9 \%-15.1 \%)$, while the high PUFA content can be extracted for other bio-products. Despite both Scrippsiella sp. samples sharing similar fatty acid profiles, significant differences $(p<0.05)$ were noted in the percentage of the fatty acid content in each. Thus, the percentage of saturated, monounsaturated, and polyunsaturated fatty acids varied between the two samples. In addition, the field sample of Scrippsiella sp. had a higher FAME content $(73 \mathrm{mg} / \mathrm{g}$ $\mathrm{dw}$ ) than that of the laboratory-cultured isolate $(55.2 \mathrm{mg} / \mathrm{g} \mathrm{dw})$. These variations may be caused by the differences in growth conditions experienced by the field sample in the real coastal environment and the cultivation conditions of the monoclonal culture in the laboratory. The field sample Scrippsiella sp., which was analyzed directly after collection, represents the native algal blooming population of Scrippsiella $s p$. and the associated microbial communities. Whereas after isolation and culturing in laboratory light and nutrient conditions, the Scrippsiella sp. were likely growing and responding differently from the blooming population in the field. Composition of microalgae-associated bacterial communities and the presence of bacterial volatile compounds can also affect growth, biomass yield, behavior, physiology, and possibly lipid productivity of microalgae [61-64]. Varying in the abundance and dominance of microbial assemblages associated with Scrippsiella $\mathrm{sp}$. in the field sample and laboratory culture may also partly contribute to the divergence in growth response, and thus their chemical constituents. As the field sample Scrippsiella sp. has not been processed prior to the analysis, the presence of environmental bacteria, though believed to be of very minor proportion, may partly contribute to the fatty acids and FAME reported.

Pre-extraction of valuable constituents, such as PUFA, carotenoids in microalgae, and the use of lipid-extracted algal residue may also provide additional value and contribute to efficient bioenergy recovery $[65,66]$. Further, lipid-extracted algal residue are rich in amino acids, sugars, vitamins, and minerals [67], which can be supplied for animal feeds and raw material in the bioethanol or biomethane production $[65,68]$. Though a critical issue of inefficient production of algal biomass, complex harvesting and high operation costs are still major limitations in commercialization [69-71], diverse utilization of algal biomass can increase the overall marketability of large-scale microalgae cultivation for commercial purposes. 
Table 5. Composition of fatty acids ( $\%$ of total FAME) and FAME yield $(\mathrm{mg} / \mathrm{g}$ of $\mathrm{dw})$ in selected algal strains. Data expressed as mean \pm SD $(\mathrm{n}=3)$.

\begin{tabular}{|c|c|c|c|c|c|c|c|c|c|c|c|c|}
\hline \multirow{2}{*}{$\begin{array}{l}\text { Species } \\
\text { Strain }\end{array}$} & \multicolumn{2}{|c|}{ P. minimum } & \multicolumn{2}{|c|}{ P. triestinum } & \multicolumn{3}{|c|}{ Scrippsiella sp. } & \multirow[t]{2}{*}{ A. sanguinea } & \multirow[t]{2}{*}{ P. germinatum } & \multirow[t]{2}{*}{ A. affine } & \multirow[t]{2}{*}{ S. rotunda } & \multirow[t]{2}{*}{ T. suecica } \\
\hline & $\mathrm{a}$ & $\mathrm{b}$ & $\mathrm{a}$ & $\mathrm{b}$ & a & $b^{*}$ & field sample^ & & & & & \\
\hline Saturated (\% of total FAME) & $13.1+1.7$ & $17.9+3.0$ & $11.3+0.0$ & $22.5+6.2$ & $13.2+1.3$ & $21.8+0.5$ & $16.1+0.4$ & $20.7+2.0$ & $13.2+1.3$ & $16.8+0.2$ & $16.9+0.6$ & $32.8+3.6$ \\
\hline Monounsaturated ( $\%$ of total FAME) & $10.9 \pm 2.3$ & $2.6 \pm 0.1$ & $2.3 \pm 0.0$ & $6.9 \pm 0.6$ & $5.7 \pm 1.2$ & $9.9 \pm 0.1$ & $15.1 \pm 2.5$ & $21.3 \pm 5.5$ & $5.7 \pm 1.2$ & $22.8 \pm 0.3$ & $3.6 \pm 0.3$ & $40.8 \pm 0.0$ \\
\hline Polyunsaturated ( $\%$ of total FAME) & $75.9 \pm 3.9$ & $79.6 \pm 2.9$ & $87.5 \pm 4.1$ & $70.7 \pm 5.7$ & $79.3 \pm 0.2$ & $67.0 \pm 0.1$ & $68.8 \pm 2.9$ & $58.0 \pm 7.5$ & $79.0 \pm 0.2$ & $60.3 \pm 0.1$ & $79.5 \pm 0.3$ & $11.3 \pm 0.0$ \\
\hline FAME content $(\mathrm{mg} / \mathrm{g}$ of $\mathrm{dw})$ & $22.7 \pm 2.2$ & $23.9 \pm 4.7$ & $27.2 \pm 0$ & $34.4 \pm 2.4$ & $32.0 \pm 2.6$ & $55.2 \pm 9.3$ & $73.0 \pm 7.5$ & $26.1 \pm 0.9$ & $21.8 \pm 9.4$ & $23.7 \pm 14.3$ & $46.1 \pm 12.3$ & $53.1 \pm 0.0$ \\
\hline
\end{tabular}

${ }^{*}$ Monoculture of Scrippsiella $s p$. in laboratory isolated from an unialgal bloom; ${ }^{\wedge}$ field-sampled Scrippsiella $s p$. from an unialgal bloom analyzed directly after collection. 


\subsection{The Potential of Harvesting Natural Algal Bloom Biomass for Biotechnological Purposes}

A similar lipid content and fatty acid profile in both laboratory-cultured and field-sampled Scrippsiella sp. collected from an algal bloom suggest the possibility of harvesting a natural algal bloom population as a mitigation strategy to harmful algal bloom and create value as biodiesel feedstock. Algal blooming biomass are unspontaneous events that cannot be regarded as a stable source for biodiesel. There could be values in biodiesel production and bioactive extraction at the advantage of natural bloom, though effectively harvesting natural algal blooming biomass can be complex and require further exploration.

Natural algal bloom biomass may be harvested with skimmer or a patented capillary extraction belt [72] or vacuum belt [73]. Sedimentation, centrifugation, filtration, flocculation, or flotation can be adopted to concentrate biomass after harvested by skimmer. Sedimentation and flocculation require lower energy input than other methods, but sedimentation is time-consuming. Flocculation can be performed biologically with addition of bacteria; chemically, with addition of organic or inorganic flocculants; electrically, by concentrating negatively-charged cells around electrodes by electrophoresis; or induce auto-flocculation by increasing the $\mathrm{pH}[23,74]$. Flocculation of dinoflagellate has been successfully performed with calcium oxide, calcium hydroxide, aluminum sulfate, and chitosan [75]. However, the addition of calcium oxide, calcium hydroxide, and aluminum sulfate can cause a shift in $\mathrm{pH}$, where chitosan remains neutral $(\mathrm{pH}=7)$. The use of $0.05 \mathrm{~g} / \mathrm{L}$ chitosan which can flocculate over $90 \%$ of Gymnodinium catenatum $(1000-3000$ cell $/ \mathrm{mL})$ may be a desirable method of harvesting dinoflagellates, especially for $\mathrm{pH}$-sensitive downstream products. The combination of chitosan, Moringa oleifera coagulant, and sand is also effective in rapidly flocculating Amphidinium carterae [76]. The Centrifugation method is reliable but of higher cost than chemical flocculation [77]. Though the use of a low efficient, high flow rate centrifugation may greatly lower costs with the selection of high lipid and a density-producing algal species [78], it is likely not applicable in harvesting slow-growing dinoflagellates.

\subsection{Other Biotechnological Applications of Fatty Acids Extracted from Microalgae}

The selected dinoflagellate strains produced a high level of PUFA in the form of DHA ( $47.5 \%-84 \%$ of total FAME). These omega-3 fatty acids can be applied in food additive, nutraceuticals, animal feed, and aquaculture feed. Fatty acids (DHA, eicosapentaenoic acid EPA, $\gamma$-linolenic acid GLA, and arachidonic acid AA), vitamins, trace elements, and amino acids in microalgae can be employed as food additive and nutraceuticals [24]. DHA is one of the key components in cell membrane and a precursor of lipid mediators. It plays a crucial role in fetal development as well as cardiovascular diseases, is involved in antioxidation and anti-inflammation, and relates to Alzheimer's disease [79]. DHA extracted from Crypthecodinium sp. and Schizochytrium sp. has been utilized in infant formula and their DHA oils are commercially available, respectively produced at 240 and 10 tons annually [80]. Microalgal-derived omega-3 can be a promising vegetarian source of DHA. It showed similar properties as those in fish oil, such as reducing the risk factor for cardiovascular diseases [81]. Crypthecodinium sp. and Schizochytrium sp. produce DHA at 30\%-50\% of total oil $[80,82]$. The analyzed dinoflagellates in the present study produced a high level of DHA (47.5\%-84\% of total FAME), which can be a potential source for DHA production. In addition to human nutrition, microalgal-derived DHA can be added in feed for poultry and aquaculture. Replacing parts of the soybean and corn meal for poultry, DHA has been observed to increase in meats, eggs, and milk under dietary intake of microalgal biomass or oil [83,84]. In aquaculture, DHA is generally enriched from fish oils [15]. Microalgae rich in long-chain PUFA have been widely applied in culturing molluscs, shrimps, and fish larvae [85]. Under a declining availability of pelagic fisheries, microalgal oil can be an alternative feed resource rich in valuable fatty acids with regard to a species-specific nutritional value and digestibility [86]. In addition, some algal species may be also applied in aquaculture with anti-microbial and immune-stimulation properties [87].

Some dinoflagellate species are known to produce toxins that can cause fish kill and pose risks to seafood safety [88]. While dinoflagellate biomass are harvested for biotechnological applications, 
risks associated to human exposure, environmental threats upon leaks to natural systems, and the disposal of biomass residue have to be considered [89]. The use of non-toxin-producing dinoflagellates, such as those species considered in the present study, strains of $A$. affine can be regarded as non-toxic with the absence of the saxitonxin gene [90] or weakly toxic [91,92], is recommended. Rat feeding safety assessment, target animal safety, and toxicity studies are also crucial prior to application in food and animal feeds. For applications with toxic dinoflagellate species, cultivation has to be carried in controlled indoor systems to reduce the risk of contamination to nearby environments. Prior toxin extraction, genetic modification, and toxicological examination on product quality could also be strategies reducing human exposure risks to the associated algal toxins.

\section{Conclusions}

The algal blooming causative agent, dinoflagellates, was evaluated to reflect the potential as renewable biodiesel feedstock. Palmitic acid (C16:0) and docosahexaenoic acid (DHA, C22:6n3) were commonly dominant in all selected algal strains. Among all assessed dinoflagellates, Scrippsiella sp. (strain $\mathrm{b}$ and the field sample) has relatively high biomass, total lipid content, and lipid productivity. These isolates yield a high lipid ( $47.3 \mathrm{mg} / \mathrm{L} /$ day) and FAME content (55.2-73 mg/g dw), which were comparable to that in green alga T. suecica. Most investigated dinoflagellates were not ideal for biodiesel production due to the low growth rate and lipid productivity. However, biotechnological applications of the high level of PUFA and other bioactive constituents in dinoflagellates are prospective for further studies. Due to high strain variations, strain-level differences should be considered when screening suitable dinoflagellates for mass cultivation. Further, this study also showed a similar lipid content and fatty acid profile in both laboratory-cultured and field-sampled Scrippsiella sp. collected from an algal bloom, suggesting the possibility of harvesting natural algal bloom population as a mitigation strategy to harmful algal bloom and create value as biodiesel feedstock. Algal blooms are unspontaneous events that cannot be regarded as a stable source for biodiesel. Though effectively harvesting algal blooming biomass can be complex and requires further evaluation, there could be potential values in biodiesel production and bioactive extraction at the advantage of natural algal bloom.

Supplementary Materials: The following are available online at http://www.mdpi.com/2077-1312/8/6/381/s1, Figure S1: Growth curves of the selected algal strains.

Author Contributions: Conceptualization, F.W.-F.L. and S.J.X.; methodology, Y.-H.Y., K.-K.C., and K.-C.W.; software, K.-C.W.; formal analysis, Y.-H.Y., K.-K.C., S.C.-Y.C., and K.-C.W.; investigation, K.-C.W., F.W.-F.L., and S.J.X.; resources, F.W.-F.L. and S.J.X.; writing-original draft preparation, K.-C.W., F.W.-F.L., and S.J.X.; writing - review and editing, S.C.-Y.C., F.W.-F.L., and S.J.X.; supervision, F.W.-F.L.; project administration, F.W.-F.L.; funding acquisition, F.W.-F.L. and S.J.X. All authors have read and agreed to the published version of the manuscript.

Funding: The research described in this paper was partially supported by The Open University of Hong Kong Research Grant No. 2018/1.9 and a grant from the Research Grants Council of the Hong Kong Special Administrative Region, China (UGC/IDS(R)16/19).

Conflicts of Interest: The authors declare no conflict of interest.

\section{References}

1. Knothe, G. "Designer" biodiesel: Optimizing fatty ester composition to improve fuel properties. Energy Fuels 2008, 22, 1358-1364. [CrossRef]

2. Chisti, Y. Biodiesel from microalgae. Biotechnol. Adv. 2007, 25, 294-306. [CrossRef]

3. Pulz, O.; Gross, W. Valuable products from biotechnology of microalgae. Appl. Microbiol. Biotechnol. 2004, 65, 635-648. [CrossRef]

4. Shuba, E.S.; Kifle, D. Microalgae to biofuels: 'Promising' alternative and renewable energy, review. Renew. Sustain. Energy Rev. 2018, 81, 743-755. [CrossRef]

5. Mathiot, C.; Ponge, P.; Gallard, B.; Sassi, J.-F.; Delrue, F.; Le Moigne, N. Microalgae starch-based bioplastics: Screening of ten strains and plasticization of unfractionated microalgae by extrusion. Carbohydr. Polym. 2019, 208, 142-151. [CrossRef] [PubMed] 
6. Greenwell, H.C.; Laurens, L.; Shields, R.; Lovitt, R.; Flynn, K. Placing microalgae on the biofuels priority list: A review of the technological challenges. J. R. Soc. Interface 2010, 7, 703-726. [CrossRef] [PubMed]

7. De-Bashan, L.E.; Bashan, Y. Immobilized microalgae for removing pollutants: Review of practical aspects. Bioresour. Technol. 2010, 101, 1611-1627. [CrossRef]

8. $\quad$ Lauritano, C.; Andersen, J.H.; Hansen, E.; Albrigtsen, M.; Escalera, L.; Esposito, F.; Helland, K.; Hanssen, K.Ø.; Romano, G.; Ianora, A. Bioactivity screening of microalgae for antioxidant, anti-inflammatory, anticancer, anti-diabetes, and antibacterial activities. Front. Mar. Sci. 2016, 3, 68. [CrossRef]

9. Sathasivam, R.; Ki, J.-S. A review of the biological activities of microalgal carotenoids and their potential use in healthcare and cosmetic industries. Mar. Drugs 2018, 16, 26. [CrossRef]

10. Mata, T.M.; Martins, A.A.; Caetano, N.S. Microalgae for biodiesel production and other applications: A review. Renew. Sustain. Energy Rev. 2010, 14, 217-232. [CrossRef]

11. Huang, G.; Chen, F.; Wei, D.; Zhang, X.; Chen, G. Biodiesel production by microalgal biotechnology. Appl. Energy 2010, 87, 38-46. [CrossRef]

12. Mascarelli, A.L. Gold rush for algae. Nature 2009, 461, 460. [CrossRef]

13. Schenk, P.M.; Thomas-Hall, S.R.; Stephens, E.; Marx, U.C.; Mussgnug, J.H.; Posten, C.; Kruse, O.; Hankamer, B. Second generation biofuels: High-efficiency microalgae for biodiesel production. Bioenergy Res. 2008, 1, 20-43. [CrossRef]

14. Banerjee, A.; Sharma, R.; Chisti, Y.; Banerjee, U. Botryococcus braunii: A renewable source of hydrocarbons and other chemicals. Crit. Rev. Biotechnol. 2002, 22, 245-279. [CrossRef]

15. Demirbaş, A. Production of biodiesel from algae oils. Energy Sources Part A 2008, 31, 163-168. [CrossRef]

16. Subashchandrabose, S.R.; Ramakrishnan, B.; Megharaj, M.; Venkateswarlu, K.; Naidu, R. Consortia of cyanobacteria/microalgae and bacteria: Biotechnological potential. Biotechnol. Adv. 2011, 29, 896-907. [CrossRef]

17. Doan, T.T.Y.; Sivaloganathan, B.; Obbard, J.P. Screening of marine microalgae for biodiesel feedstock. Biomass Bioenergy 2011, 35, 2534-2544. [CrossRef]

18. Ghasemi, Y.; Rasoul-Amini, S.; Naseri, A.T.; Montazeri-Najafabady, N.; Mobasher, M.A.; Dabbagh, F. Microalgae biofuel potentials. Appl. Biochem Microbiol. 2012, 48, 126-144. [CrossRef]

19. Fuentes-Grünewald, C.; Garcés, E.; Rossi, S.; Camp, J. Use of the dinoflagellate Karlodinium veneficum as a sustainable source of biodiesel production. J. Ind. Microbiol. Biotechnol. 2009, 36, 1215-1224. [CrossRef]

20. Delrue, F.; Setier, P.-A.; Sahut, C.; Cournac, L.; Roubaud, A.; Peltier, G.; Froment, A.-K. An economic, sustainability, and energetic model of biodiesel production from microalgae. Bioresour. Technol. 2012, 111, 191-200. [CrossRef]

21. Chen, J.; Li, J.; Dong, W.; Zhang, X.; Tyagi, R.D.; Drogui, P.; Surampalli, R.Y. The potential of microalgae in biodiesel production. Renew. Sustain. Energy Rev. 2018, 90, 336-346. [CrossRef]

22. Abomohra, A.E.-F.; Jin, W.; Tu, R.; Han, S.-F.; Eid, M.; Eladel, H. Microalgal biomass production as a sustainable feedstock for biodiesel: Current status and perspectives. Renew. Sustain. Energy Rev. 2016, 64, 596-606. [CrossRef]

23. Milledge, J.J.; Heaven, S. A review of the harvesting of micro-algae for biofuel production. Rev. Environ. Sci. Biotechnol. 2013, 12, 165-178. [CrossRef]

24. Brennan, L.; Owende, P. Biofuels from microalgae-A review of technologies for production, processing, and extractions of biofuels and co-products. Renew. Sustain. Energy Rev. 2010, 14, 557-577. [CrossRef]

25. Yang, J.; Xu, M.; Zhang, X.; Hu, Q.; Sommerfeld, M.; Chen, Y. Life-cycle analysis on biodiesel production from microalgae: Water footprint and nutrients balance. Bioresour. Technol. 2011, 102, 159-165. [CrossRef]

26. Agricultural, Fisheries and Conservation Department, HKSAR. Hong Kong Red Tide Information Network. Available online: https://www.afcd.gov.hk/english/fisheries/hkredtide/redtide.html (accessed on 20 May 2020).

27. Gobler, C.J. Climate change and harmful algal blooms: Insights and perspective. Harmful Algae 2020, 91, 101731. [CrossRef]

28. Samarakoon, K.W.; Ko, J.-Y.; Shah, M.M.R.; Lee, J.-H.; Kang, M.-C.; Kwon, O.-N.; Lee, J.-B.; Jeon, Y.-J. In vitro studies of anti-inflammatory and anticancer activities of organic solvent extracts from cultured marine microalgae. Algae 2013, 28, 111-119. [CrossRef]

29. Assunção, J.; Guedes, A.; Malcata, F.X. Biotechnological and pharmacological applications of biotoxins and other bioactive molecules from dinoflagellates. Mar. Drugs 2017, 15, 393. [CrossRef] 
30. Fuentes-Grünewald, C.; Garcés, E.; Alacid, E.; Rossi, S.; Camp, J. Biomass and lipid production of dinoflagellates and raphidophytes in indoor and outdoor photobioreactors. Mar. Biotechnol. 2013, 15, 37-47. [CrossRef]

31. Fuentes-Grünewald, C.; Bayliss, C.; Fonlut, F.; Chapuli, E. Long-term dinoflagellate culture performance in a commercial photobioreactor: Amphidinium carterae case. Bioresour. Technol. 2016, 218, 533-540. [CrossRef]

32. Go, S.; Lee, S.-J.; Jeong, G.-T.; Kim, S.-K. Factors affecting the growth and the oil accumulation of marine microalgae, Tetraselmis suecica. Bioprocess. Biosyst. Eng. 2012, 35, 145-150. [CrossRef]

33. Griffiths, M.J.; van Hille, R.P.; Harrison, S.T. Lipid productivity, settling potential and fatty acid profile of 11 microalgal species grown under nitrogen replete and limited conditions. J. Appl. Phycol. 2012, 24, 989-1001. [CrossRef]

34. Moheimani, N.R. Long-term outdoor growth and lipid productivity of Tetraselmis suecica, Dunaliella tertiolecta and Chlorella sp. (Chlorophyta) in bag photobioreactors. J. Appl. Phycol. 2013, 25, 167-176. [CrossRef]

35. Keller, M.D.; Selvin, R.C.; Claus, W.; Guillard, R.R.L. Media for the Culture of Oceanic Ultraphytoplankton. J. Phycol. 1987, 23, 633-638. [CrossRef]

36. Lee, F.W.-F.; Ho, K.C.; Lo, S.C.-L. Rapid identification of dinoflagellates using protein profiling with matrix-assisted laser desorption/ionization mass spectrometry. Harmful Algae 2008, 7, 551-559. [CrossRef]

37. Adachi, M.; Sako, Y.; Ishida, Y. Restriction fragment length polymorphism of ribosomal DNA internal transcribed spacer and 5.8s regions in Japanese Alexandrium species (Dinophyceae). J. Phycol. 1994, 30, 857-863. [CrossRef]

38. Adachi, M.; Sake, Y.; Ishida, Y. Analysis of Alexandrium (Dinophyceae) species using sequences of the $5.8 \mathrm{~S}$ ribosomal DNA and internal transcribed spacer regions 1. J. Phycol. 1996, 32, 424-432. [CrossRef]

39. Thompson, J.D.; Gibson, T.J.; Plewniak, F.; Jeanmougin, F.; Higgins, D.G. The CLUSTAL_X Windows Interface: Flexible Strategies for Multiple Sequence Alignment Aided by Quality Analysis Tools. Nucleic Acids Res. 1997, 25, 4876-4882. [CrossRef]

40. Arenas, N.E.; Polanco, J.C.; Coronado, S.M.; Durango, C.J.; Gómez, A. Design of a molecular method for subspecies specific identification of Klebsiella pneumoniae by using the $16 \mathrm{~S}$ ribosomal subunit gene. Colomb. Médica 2009, 40, 194-201.

41. Goldman, J.C.; Dennett, M.R. Susceptibility of some marine phytoplankton species to cell breakage during filtration and post-filtration rinsing. J. Exp. Mar. Biol. Ecol. 1985, 86, 47-58. [CrossRef]

42. Bligh, E.G.; Dyer, W.J. A rapid method of total lipid extraction and purification. Can. J. Biochem. Physiol. 1959, 37, 911-917. [CrossRef]

43. Lepage, G.; Roy, C.C. Improved recovery of fatty acid through direct transesterification without prior extraction or purification. J. Lipid Res. 1984, 25, 1391-1396. [PubMed]

44. Griffiths, M.J.; Harrison, S.T. Lipid productivity as a key characteristic for choosing algal species for biodiesel production. J. Appl. Phycol. 2009, 21, 493-507. [CrossRef]

45. Langer, G.; Nehrke, G.; Probert, I.; Ly, J.; Ziveri, P. Strain-specific responses of Emiliania huxleyi to changing seawater carbonate chemistry. Biogeosciences 2009, 6, 2637-2646. [CrossRef]

46. Kremp, A.; Godhe, A.; Egardt, J.; Dupont, S.; Suikkanen, S.; Casabianca, S.; Penna, A. Intraspecific variability in the response of bloom-forming marine microalgae to changed climate conditions. Ecol. Evol. 2012, 2, 1195-1207. [CrossRef]

47. Sassenhagen, I.; Wilken, S.; Godhe, A.; Rengefors, K. Phenotypic plasticity and differentiation in an invasive freshwater microalga. Harmful Algae 2015, 41, 38-45. [CrossRef]

48. Rodolfi, L.; Chini Zittelli, G.; Bassi, N.; Padovani, G.; Biondi, N.; Bonini, G.; Tredici, M.R. Microalgae for oil: Strain selection, induction of lipid synthesis and outdoor mass cultivation in a low-cost photobioreactor. Biotechnol. Bioeng. 2009, 102, 100-112. [CrossRef]

49. Weldy, C.S.; Huesemann, M. Lipid production by Dunaliella salina in batch culture: Effects of nitrogen limitation and light intensity. J. Undergrad. Res. 2007, 7, 115-122.

50. Converti, A.; Casazza, A.A.; Ortiz, E.Y.; Perego, P.; Del Borghi, M. Effect of temperature and nitrogen concentration on the growth and lipid content of Nannochloropsis oculata and Chlorella vulgaris for biodiesel production. Chem. Eng. Process. Process. Intensif. 2009, 48, 1146-1151. [CrossRef] 
51. Nascimento, I.A.; Marques, S.S.I.; Cabanelas, I.T.D.; Pereira, S.A.; Druzian, J.I.; de Souza, C.O.; Vich, D.V.; de Carvalho, G.C.; Nascimento, M.A. Screening microalgae strains for biodiesel production: Lipid productivity and estimation of fuel quality based on fatty acids profiles as selective criteria. Bioenergy Res. 2013, 6, 1-13. [CrossRef]

52. Sajjadi, B.; Chen, W.-Y.; Raman, A.A.A.; Ibrahim, S. Microalgae lipid and biomass for biofuel production: A comprehensive review on lipid enhancement strategies and their effects on fatty acid composition. Renew. Sustain. Energy Rev. 2018, 97, 200-232. [CrossRef]

53. Lin, S. Genomic understanding of dinoflagellates. Res. Microbiol. 2011, 162, 551-569. [CrossRef]

54. ASTM. D6751 Standard Specification for Biodiesel Fuel Blend Stock (B100) for Middle Distillate Fuels. Available online: http://203.187.160.133:9011/agrifuelsqcs-i.com/c3pr90ntc0td/attachments/1263\%20/d6751. 46391.pdf (accessed on 20 May 2020).

55. Lee, J.-Y.; Yoo, C.; Jun, S.-Y.; Ahn, C.-Y.; Oh, H.-M. Comparison of several methods for effective lipid extraction from microalgae. Bioresour. Technol. 2010, 101, S75-S77. [CrossRef] [PubMed]

56. Harrington, K.J. Chemical and physical properties of vegetable oil esters and their effect on diesel fuel performance. Biomass 1986, 9, 1-17. [CrossRef]

57. Knothe, G.; Matheaus, A.C.; Ryan, T.W., III. Cetane numbers of branched and straight-chain fatty esters determined in an ignition quality tester. Fuel 2003, 82, 971-975. [CrossRef]

58. Automotive Fuels. Fatty Acid Methylesters (FAME) for Diesel Engines. Requirements and Test Methods, British Standard. 2008. Available online: https:/www.sis.se/en/produkter/petroleum-andrelated-technologies/fuels/liquid-fuels/ssen14214/ (accessed on 20 May 2020).

59. Knothe, G. Analyzing biodiesel: Standards and other methods. J. Am. Oil Chem. Soc. 2006, 83, 823-833. [CrossRef]

60. Grünewald, C.F. Dinoflagellates as feedstock for biodiesel production. In The Science of Algal Fuels. Cellular Origin, Life in Extreme Habitats and Astrobiology; Gordon, R., Seckbach, J., Eds.; Springer: Dordrecht, The Netherlands, 2012; Volume 25, pp. 233-254.

61. Lee, J.; Cho, D.-H.; Ramanan, R.; Kim, B.-H.; Oh, H.-M.; Kim, H.-S. Microalgae-associated bacteria play a key role in the flocculation of Chlorella vulgaris. Bioresour. Technol. 2013, 131, 195-201. [CrossRef]

62. Bolch, C.J.; Bejoy, T.A.; Green, D.H. Bacterial associates modify growth dynamics of the dinoflagellate Gymnodinium catenatum. Front. Microbiol. 2017, 8, 670. [CrossRef]

63. Cho, K.; Heo, J.; Cho, D.-H.; Tran, Q.-G.; Yun, J.-H.; Lee, S.-M.; Lee, Y.J.; Kim, H.-S. Enhancing algal biomass and lipid production by phycospheric bacterial volatiles and possible growth enhancing factor. Algal Res. 2019, 37, 186-194. [CrossRef]

64. Berthold, D.E.; Shetty, K.G.; Jayachandran, K.; Laughinghouse, H.D., IV; Gantar, M. Enhancing algal biomass and lipid production through bacterial co-culture. Biomass Bioenergy 2019, 122, 280-289. [CrossRef]

65. Soratana, K.; Barr, W.J.; Landis, A.E. Effects of co-products on the life-cycle impacts of microalgal biodiesel. Bioresour. Technol. 2014, 159, 157-166. [CrossRef] [PubMed]

66. Damergi, E.; Schwitzguébel, J.-P.; Refardt, D.; Sharma, S.; Holliger, C.; Ludwig, C. Extraction of carotenoids from Chlorella vulgaris using green solvents and syngas production from residual biomass. Algal Res. 2017, 25, 488-495. [CrossRef]

67. Matos, Â.P.; Feller, R.; Moecke, E.H.S.; de Oliveira, J.V.; Junior, A.F.; Derner, R.B.; Sant'Anna, E.S. Chemical characterization of six microalgae with potential utility for food application. J. Am. Oil Chem. Soc. 2016, 93, 963-972. [CrossRef]

68. Lee, O.K.; Oh, Y.-K.; Lee, E.Y. Bioethanol production from carbohydrate-enriched residual biomass obtained after lipid extraction of Chlorella sp. KR-1. Bioresour. Technol. 2015, 196, 22-27. [CrossRef]

69. Norsker, N.-H.; Barbosa, M.J.; Vermuë, M.H.; Wijffels, R.H. Microalgal production-A close look at the economics. Biotechnol. Adv. 2011, 29, 24-27. [CrossRef]

70. Singh, A.; Nigam, P.S.; Murphy, J.D. Mechanism and challenges in commercialisation of algal biofuels. Bioresour. Technol. 2011, 102, 26-34. [CrossRef]

71. Abdullah, B.; Muhammad, S.A.F.S.; Shokravi, Z.; Ismail, S.; Kassim, K.A.; Mahmood, A.N.; Aziz, M.M.A. Fourth generation biofuel: A review on risks and mitigation strategies. Renew. Sustain. Energy Rev. 2019, 107, 37-50. [CrossRef]

72. Youngs, R.O.; Cook, J.R. Method and Apparatus for Separating Particles from a Liquid. U.S. Patent US8092691B2, 10 January 2012. 
73. Shepherd, S.L. System for Harvesting Algae in Continuous Fermentation. U.S. Patent US8377687B2, 19 February 2013.

74. Kadir, W.N.A.; Lam, M.K.; Uemura, Y.; Lim, J.W.; Lee, K.T. Harvesting and pre-treatment of microalgae cultivated in wastewater for biodiesel production: A review. Energy Convers. Manag. 2018, 171, 1416-1429. [CrossRef]

75. Martínez, T.d.C.C.; Rodríguez, R.A.; Voltolina, D.; Morquecho, L. Effectiveness of coagulants-flocculants for removing cells and toxins of Gymnodinium catenatum. Aquaculture 2016, 452, 188-193. [CrossRef]

76. Li, L.; Pan, G. A universal method for flocculating harmful algal blooms in marine and fresh waters using modified sand. Environ. Sci. Technol. 2013, 47, 4555-4562. [CrossRef]

77. Wang, S.; Yerkebulan, M.; Abomohra, A.E.-F.; El-Khodary, S.; Wang, Q. Microalgae harvest influences the energy recovery: A case study on chemical flocculation of Scenedesmus obliquus for biodiesel and crude bio-oil production. Bioresour. Technol. 2019, 286, 121371. [CrossRef]

78. Dassey, A.J.; Theegala, C.S. Harvesting economics and strategies using centrifugation for cost effective separation of microalgae cells for biodiesel applications. Bioresour. Technol. 2013, 128, 241-245. [CrossRef]

79. Swanson, D.; Block, R.; Mousa, S.A. Omega-3 fatty acids EPA and DHA: Health benefits throughout life. Adv. Nutr. 2012, 3, 1-7. [CrossRef]

80. Spolaore, P.; Joannis-Cassan, C.; Duran, E.; Isambert, A. Commercial applications of microalgae. J. Biosci. Bioeng. 2006, 101, 87-96. [CrossRef]

81. Haimeur, A.; Mimouni, V.; Ulmann, L.; Martineau, A.-S.; Messaouri, H.; Pineau-Vincent, F.; Tremblin, G.; Meskini, N. Fish oil and microalga omega-3 as dietary supplements: A comparative study on cardiovascular risk factors in high-fat fed rats. Lipids 2016, 51, 1037-1049. [CrossRef]

82. Doughman, S.D.; Krupanidhi, S.; Sanjeevi, C.B. Omega-3 fatty acids for nutrition and medicine: Considering microalgae oil as a vegetarian source of EPA and DHA. Current Diabetes Rev. 2007, 3, 198-203. [CrossRef]

83. Stamey, J.; Shepherd, D.; De Veth, M.; Corl, B. Use of algae or algal oil rich in n-3 fatty acids as a feed supplement for dairy cattle. J. Dairy Sci. 2012, 95, 5269-5275. [CrossRef]

84. Lum, K.K.; Kim, J.; Lei, X.G. Dual potential of microalgae as a sustainable biofuel feedstock and animal feed. J. Anim. Sci. Biotechnol. 2013, 4, 53. [CrossRef]

85. Brown, M.; Robert, R. Preparation and assessment of microalgal concentrates as feeds for larval and juvenile Pacific oyster (Crassostrea gigas). Aquaculture 2002, 207, 289-309. [CrossRef]

86. Chauton, M.S.; Reitan, K.I.; Norsker, N.H.; Tveterås, R.; Kleivdal, H.T. A techno-economic analysis of industrial production of marine microalgae as a source of EPA and DHA-rich raw material for aquafeed: Research challenges and possibilities. Aquaculture 2015, 436, 95-103. [CrossRef]

87. Charoonnart, P.; Purton, S.; Saksmerprome, V. Applications of microalgal biotechnology for disease control in aquaculture. Biology 2018, 7, 24. [CrossRef] [PubMed]

88. Wang, D.-Z. Neurotoxins from marine dinoflagellates: A brief review. Mar. Drugs 2008, 6, 349-371. [CrossRef] [PubMed]

89. Menetrez, M.Y. An overview of algae biofuel production and potential environmental impact. Environ. Sci. Technol. 2012, 46, 7073-7085. [CrossRef] [PubMed]

90. Lee, K.H.; Jeong, H.J.; Kwon, J.E.; Kang, H.C.; Kim, J.H.; Jang, S.H.; Park, J.Y.; Yoon, E.Y.; Kim, J.S. Mixotrophic ability of the phototrophic dinoflagellates Alexandrium andersonii, A. affine, and A. fraterculus. Harmful Algae 2016, 59, 67-81. [CrossRef] [PubMed]

91. Hold, G.L.; Smith, E.A.; Rappë, M.S.; Maas, E.W.; Moore, E.R.; Stroempl, C.; Stephen, J.R.; Prosser, J.I.; Birkbeck, T.H.; Gallacher, S. Characterisation of bacterial communities associated with toxic and non-toxic dinoflagellates: Alexandrium spp. and Scrippsiella trochoidea. FEMS Microbiol. Ecol. 2001, 37, 161-173. [CrossRef]

92. Nguyen-Ngoc, L. An autecological study of the potentially toxic dinoflagellate Alexandrium affine isolated from Vietnamese waters. Harmful Algae 2004, 3, 117-129. [CrossRef]

(C) 2020 by the authors. Licensee MDPI, Basel, Switzerland. This article is an open access article distributed under the terms and conditions of the Creative Commons Attribution (CC BY) license (http://creativecommons.org/licenses/by/4.0/). 